\title{
5. AGE AND SEX PATTERNS OF PERSONS SUSPECTED OF COMMITTING OFFENCES IN ŁÓDŹ ${ }^{1}$
}

\subsection{INITIAL REMARKS}

Researching demographic patterns of persons committing offences has had a long tradition among various science domains analysing different issues related to crime. That is so because it is interesting to seek answers to why in populations with specific patterns some individuals commit offences while others completely refrain from such actions. The existence of criminal and deviant behaviours is influenced by the following demographic features: age, sex (biological and social - gender), race, nuptiality, procreation ratio, migrations, and spatial redistribution of the population (South, Messner 2000; Rotolo, Tittle 2006).

The claim that there is a relationship between sex and age and crime rate is one of the oldest and the most widely accepted notions in contemporary criminology. Throughout the world, it is justifiable to indicate men as the main culprits; also in the case of age patterns of offenders, it is a widely known regularity that the tendency to commit offences decreases with the increase of the age of the potential culprit. Among various sociological theories, there is a traditional view derived from the theories of Thomas Hobbes where people's behaviour, particularly in their early years, is not compliant in its nature with social norms and contracts. Said theories propose that the highest crime rate is

\footnotetext{
${ }^{1}$ This article was written under a grant financed by the National Science Centre entitled "Dysproporcje społeczne i gospodarcze w przestrzeni Łodzi. Czynniki, mechanizmy, skutki" (Social and economic inequality in Łódź. Factors, mechanisms, consequences), no. NN 306033040.
} 
found among adolescent people and decreases as they become older (this decrease may be faster for some acts and slow for other torts). This problem was well illustrated by Norman Ryder who said: "Society at large is faced perennially with an invasion of barbarians ... [and] every adult generation is faced with the task of civilizing those barbarians” (Morgan, Kunkel 2007; p. 35). Under the term "civilize", Ryder understood the socialisation with age, social integration and social control which generally lead to lowering of profits derived from crime. It seems, however, that despite evident decrease of criminal tendencies among older age groups, there are noticeable differences among the share of individual age groups committing torts, which are comparable for various areas or locations (Cohen, Land 1987; Steffensmeier, Allan 1996; Mordwa 2013; Błachut et al 2007). The goal of this study is to prove that in the case of sex and age patterns, even within the same city, the proportions between different age groups of suspects are variable.

As for the age of culprits, one can formulate the following regularities: - the relationship between tendency and committing offences and age is reverse which entails a decrease of the tendency among older people; - younger people commit more offences regardless of other social and economic factors (economic status, marital status, race, sex etc.); - repeat offenders start their criminal activity already as children (in Poland, even before the age of 13); initially, the tendency rises quickly only to gradually decrease with age; - younger offenders rather commit offences against property and using force while older people are more often arrested for drunkenness, driving under the influence or shoplifting; young people rather than adults commit criminal offences in cooperation with other people; - the main reasons why juveniles ${ }^{2}$ commit offences are the will to gain money, to impress others, of a sense of impunity, seeking acceptance and sense of security among the members of informal youth groups (Cohen, Land 1987; Laskowski et al 1996; Agnew 2003; Siegel 2012; Mordwa 2013).

There are various theories attempting to explain the relationship between the tendency to commit offences and the young age of the culprits. According to Robert Agnew, the peek of human criminal activity in young age may be related to the elements of maturing in the modern post-industrial society. It is

${ }^{2}$ In Polish law, a juvenile is a person under the age of 17 . Such a person is not punishable by law and cannot be referred to as a criminal. However, if a person aged 15 or more commits certain acts, he/she may face prosecution as specified in the penal code (Art. 10 of the Penal Code; J. of. L. 1997, No. 88 Item 553). The procedure in the case of minors is generally regulated by a separate minors' procedure act (J. of. L. 1982 No. 35 Item 228). Additionally, the penal code also identifies a group called młodociani (young offenders) (Art. 115 (10) of the Penal Code): "a young offender is an offender who at the time of infringing the law is under 21 years of age and under 24 years of age when adjudication in the court of first instance occurs". 
complimented by lower adult supervision, the need to gain adult privileges, increased requirements regarding economic success and upward social mobility, and decreased ability to cope using legally allowable means. There are also researchers who consider criminal activity as "normal" behaviour, simply specific for the period of adolescence (Brown et al. 2010). Researchers who have studied the development of criminal careers found that criminal activity decreases during the process of normal biological and socio-psychological development and that as people become older they are able to assess more precisely the probability of success of an offence. Neal Shover and Carol Thompson describe this rule in the following manner: "the allure of crime diminishes substantially as offenders get older” (Reid 2000, p. 44).

In the case of suspects' sex, literature offers some regularities which characterise crime also in Poland. Those are: - the existence of relatively constant share of convicted women (6-7 women per 100 convictions in the last few years); - women more often commit offences: against property, against justice authorities, against the family, inducing into prostitution or falsifying personal information (whereas they far more rarely commit such crimes as rapes, lewd conduct against juveniles, vehicle theft, abusing family members, aggravated theft or burglary); - with age, the share of women being convicted rises; - women are less likely to return to crime than men; - according to Albert Cohen: "The most conspicuous difference between male and female delinquency is that male delinquency... is versatile and female delinquency is relatively specialized. It consists overwhelmingly of sexual delinquency" (Brown et al. 2010, p. 108); - even though men are responsible for the majority of serious offences, according to Larry Siegel, the dynamics of committing those acts in the last few years has been higher among women and it is them who have been a growing group among arrestees (Siegel 2012).

Using the output of various domains of science, many researchers attempted explaining the phenomenon of the generally lower tendency among women to commit offences. However, considering Polish specificity, one must consider the claim by Jan Szczepański who assumes the general cultural approach. This acclaimed Polish sociologist claimed that the complete set of cultural phenomena considerably influences the diversification of the roles played by both sexes. Thus, there is a specific system of values because of which people expect different behaviour from men and women. The idea of the role played by women forces them to subordinate their individual goals and aspirations to the acknowledged value: being a wife and a mother (Szczepański 1972). James Treadwell (2006) indicated similar reasons for lower delinquency among women. He believed that men simply possess more physical strength than women and are more aggressive, yet they often lack cultural traits commonly assigned to women, such as compassion, empathy, and the need to look after 
others. This may be a result of the fact that boys are brought up cherishing physical strength, dominance and aggression whereas girls are rewarded for displaying stereotypically female qualities. According to Treadwell, it is impossible to clearly state why women commit crimes less often than men at this stage of the analysis of the phenomenon.

At this point, it is necessary to highlight some statistical and institutional conditions which result in underestimation of the number of acts committed by women. Women commit acts (usually of low gravity) which are rarely detected or reported and which are often solved informally. Furthermore, in the case of women, the police file less reports to the prosecution and judges are more likely to adjudicate minor danger of the acts and they adjudicate lower penalties (Leśniak 1998; Hołyst 2009).

In this study, I will present analyses of age and sex patterns of people suspected of committing offences in Łódź in 2006-2010, based on the data received from the Voivodeship Police Department (hereinafter, I will use various average values of this notion). It must be stated that there are significant differences between such notions as: a suspect, the accused and a criminal. A suspect is a person towards whom a decision has been issued to present charges and only some suspects become the accused, i.e. persons against whom charges were filed. Upon adjudication in a criminal case (conviction, conditional discontinuance, discontinuance, acquittal) some accused are convicted. Criminals are the convicted who were proved to had committed an illegal act.

Below, I offer a profile of suspects who were registered in the TEMIDA Police Crime Statistics System. It is worth noticing that, in the case of Łódź data, the recorded number of suspects $(9,500)$ and the number of offences committed $(29,800$ acts) diverge - Fig. 1 . This is chiefly a result of Łódź being a city with the lowest crime detection rate (44\% in 2006-2010) and of the fact that suspects are recorded in the TEMIDA system only once within a given period of time - in relation to an act which carries the highest penalty, yet a given person may be accused of committing more acts within the same period. The discrepancy between the number of detected offences and the number of suspects is also a result of the fact that more than one suspect may be detected to had participated in an act, but there are also situations when one accused is responsible of committing many acts simultaneously. Thus, in the case of the different patterns analysed, there might be a difference between the total number of suspects further underestimated by the number of persons for whom a given feature has not been defined. 


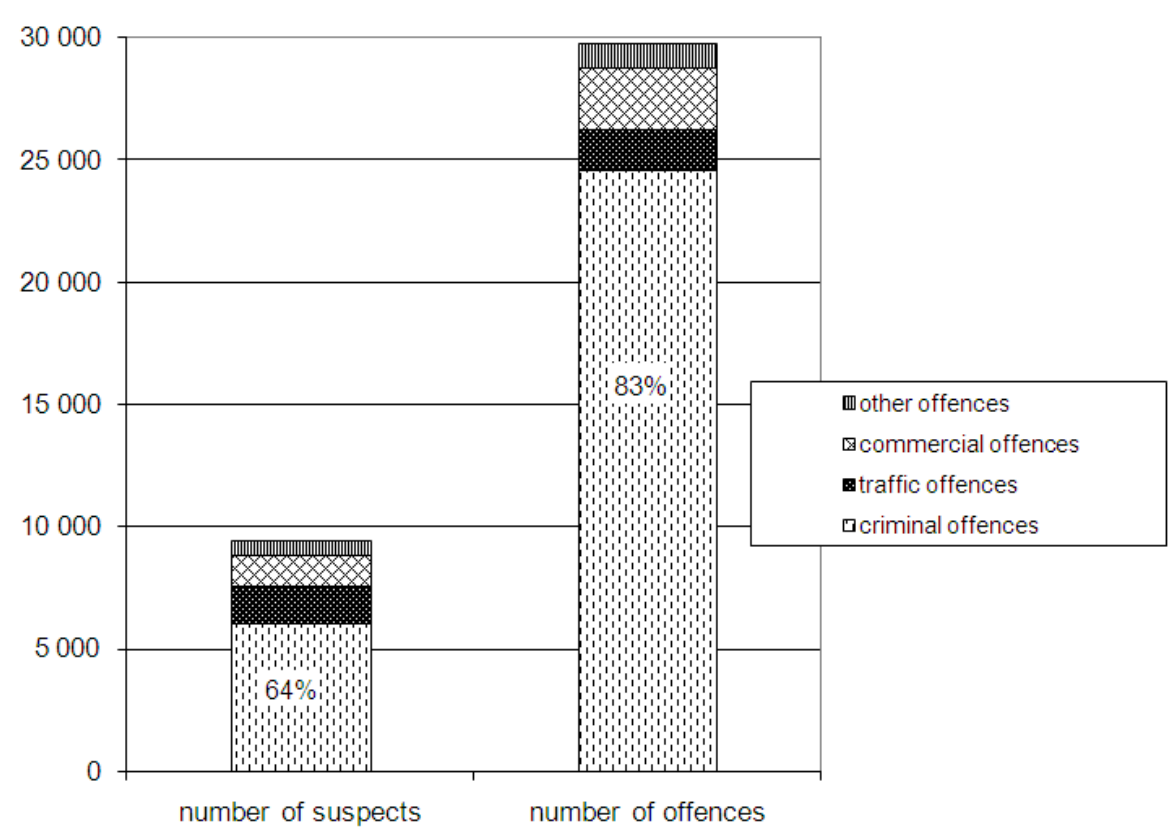

Fig. 1. Average number of suspects and offences committed in Łódź in 2006-2010 (own work)

\subsection{SEX OF PERSONS SUSPECTED OF COMMITTING OFFENCES IN LÓDŹ}

Between 2006 and 2010, 33,200 to 27,100 illegal acts were recorded annually in Łódź, i.e. 398 illegal acts per 10,000 inhabitants. This value is high when viewed nationally, however, considering the total population of the city, Łódź is not a city with exceptionally high crime rate (Mordwa 2013). When addressing spatial patterns of committed offences, their highest number (Fig. 3) occurred within the areas of precincts: I (Śródmieście) - 822 acts per 10,000 inhabitants, IV (eastern Polesie) - 641 and II (western Bałuty) - 478. Areas of peripherally located precincts II (western Polesie) - 262 and VII (southern Górna) - 287 were safer.

As for offences confirmed in Łódź, sex was determined in the case of 47,270 suspects - those were mainly men (84\%) as compared to women (16\% - Polish average for women is ca. $10 \%$ ). It can be stated that in Łódź, women display a certain specialisation in specific types of torts they commit. The analysed data indicates that they commit more than twice as many commercial crimes (33\% of 
suspects) and slightly more criminal acts against property (Fig. 2). Women are less likely to commit traffic and other offences $(11 \%)^{3}$.

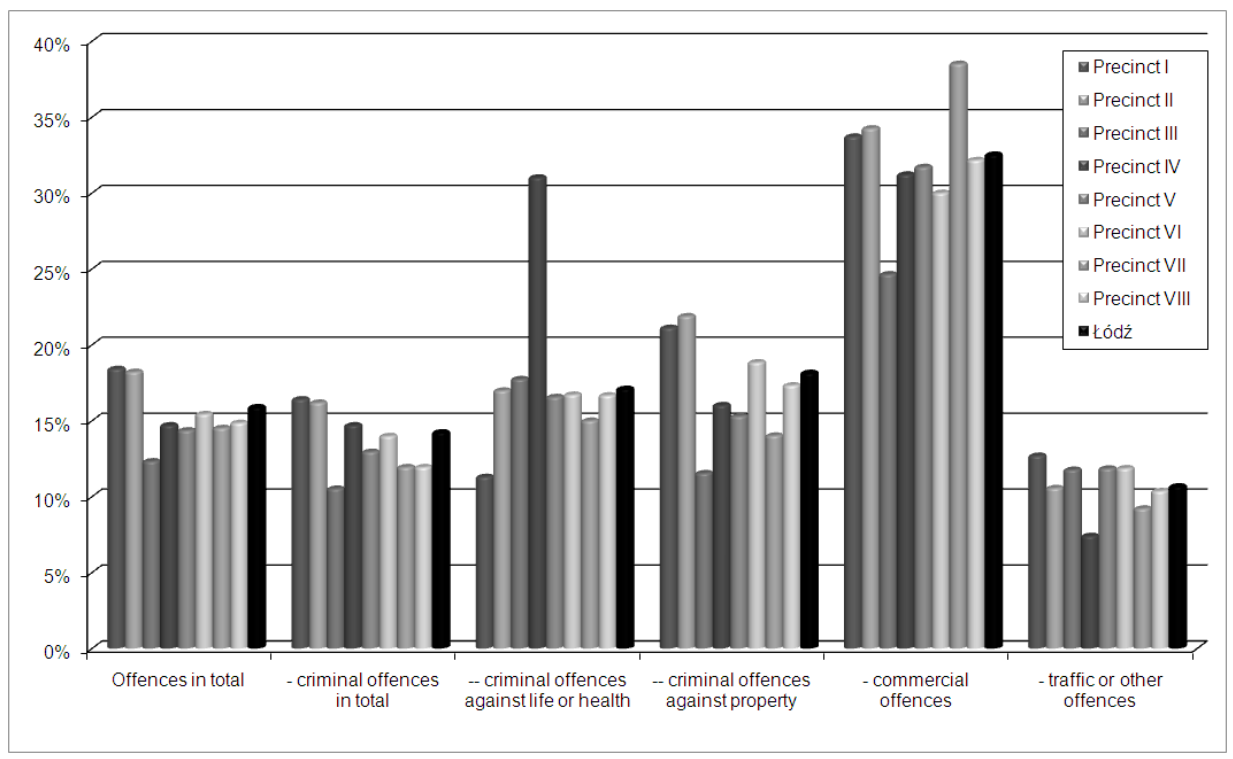

Fig. 2. Percentage of women suspected of committing offences in Łódź in 2006-2010 (own work)

When comparing different areas of the city, it becomes visible that sex patterns are not constant - the percentage of women and men among all suspects (even in relation to the same categories of crimes) vary across Łódź (Fig. 2). The highest share of women suspected of committing torts was confirmed in precincts I and II reaching $18 \%$ while in precinct III - only $12 \%$. As for specific groups of offences, the percentage of women suspects varies even further reaching $\pm 20 \%$ for specific precincts when compared to the general value for Łódź. Particularly higher variation has been found in the case of offences against life or health and property. Within precinct IV, the percentage of women suspects exceeds the general value for Łódź by $81 \%$ (reaching $31 \%$ ), whereas in Śródmieście, the percentage is lower by $34 \%$ (reaching only $11 \%$ ). It has been observed that the percentage of women suspected of committing torts is generally higher in areas with higher crime rates. This means that women's

${ }^{3}$ Such a low indicator is a result of the fact that the most common offence in this group is driving a motor vehicle or other vehicle under the influence. Women commit ca. $3 \%$ of such offences (thus, it is mostly men who drive "after having one too many"). However, if one looks at offences such as causing a road accident, one will find women commit nearly $20 \%$ of such offences (statystyka.policja.pl). 
criminal activity is higher in areas which suffer from increased intensity of the phenomenon (Śródmieście, western Bałuty, eastern Polesie) - as if criminal areas would spur women into committing illegal acts. It seems that in Łódź, women's criminal "activity" is higher in areas where more offences and criminals are recorded.

One could draw similar conclusions when analysing the spatial distribution of the intensity index of crime calculated for both sexes (Fig. 3). The map shows that the highest percentage of suspects among the inhabitants of a given precinct is visible in the city centre (precincts I and IV). In Śródmieście, as much as 86 women and 464 men (per 10,000 inhabitants of the respective sex) were suspected of committing a tort. This is three times (men) and five times (women) higher than in precinct III (152 men and 18 women were suspects per 10,000 inhabitants of the respective sex). Additionally, one might observe that the intensification of female crime rates is related to the urban environment. Even though women are several times less likely to be suspected of committing a tort than men within the same area of the city, it is noticeable that, e.g. men from western Polesie are only twice as criminally active (152 suspects per 10,000 inhabitants) as women from Śródmieście (86). Thus, it seems possible to indicate areas where illegal activity of women and men is particularly increased and those where it is less frequent. Therefore, in the case of suspects, sex is in Łódź a factor diversifying crime both in terms of spatial diversification and in terms of offences committed.

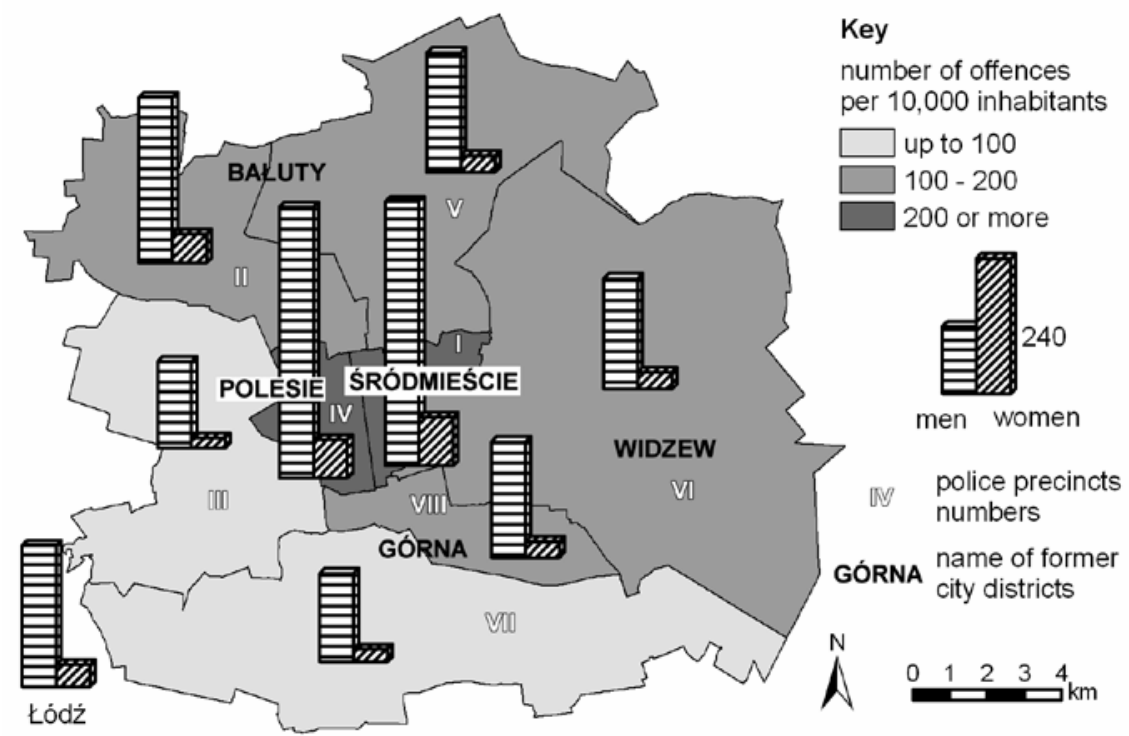

Fig. 3. Intensity index of the number of suspects per precinct in Łódź in 2006-2010 (own work) 


\subsection{AgE OF PERSONS SUSPECTED OF COMMITTING OFFENCES IN LÓDŹ}

The age of persons suspected of committing offences is lower than the age patterns of all inhabitants of the city would indicate. The median of the age of Łódź inhabitants in 2006-2010 was 44.9 and it varied between precincts from 41.8 (eastern Polesie) to 47.7 (western Polesie) while among 47,900 suspects who were detected within the five-year period in Łódź (9,562 people on average annually), the median was only 29.5. On average, the youngest suspects were detected in precinct VII - southern Górna and IV - eastern Polesie (median was 25 and 27.7 respectively) and the oldest in precincts V (eastern Bałuty) and VI (Widzew) - medians of 31.8 and 31.5 respectively (Fig. 4). The largest group among suspects consisted of people aged 21-29 (28\%), followed by 30-39 (21\%) and people in their forties (14\%). A slightly different distribution of suspects among specific age groups is offered when taking into account the number of inhabitants at the same age. Analysis of such indicators showed the highest intensity of crime among youth suspects aged 17-20 - 330 people per every 10,000 inhabitants at the same age. Crime rate is also high among people in their twenties (315); among people in their thirties, there were 207 and among people in their forties - 138 per every 10,000 inhabitants. Among juveniles under 17, there were 25 people suspected of committing a torts in Łódź, i.e. only slightly less than the general share of suspects in all age groups which reached 134 suspects. The oldest people (aged over 60) constitute the smallest group of suspects - only 3\% which translates into 17 people detected per every 10,000 inhabitants of Łódź at that age. In total, adults constituted $77 \%$ of all suspects, youth suspects $-11 \%$, and juveniles $-12 \%$.

Spatial diversification of the share of specific age groups of suspect within the areas of eight precincts is distinct. For example, the share of juveniles differs between less than $10 \%$ in Śródmieście to more than $15 \%$ in precinct VIII (northern Górna). The lower the share of juvenile suspects, the higher the share of youth suspects: in precinct I more than $12 \%$. The two groups of the youngest suspects together are the most distinct in terms of numbers in precincts IV and VIII where they constitute more than $25 \%$ of the total number of suspects. There is also a significant spatial diversification in the case of the remaining age groups, as illustrated in Fig. 4. 


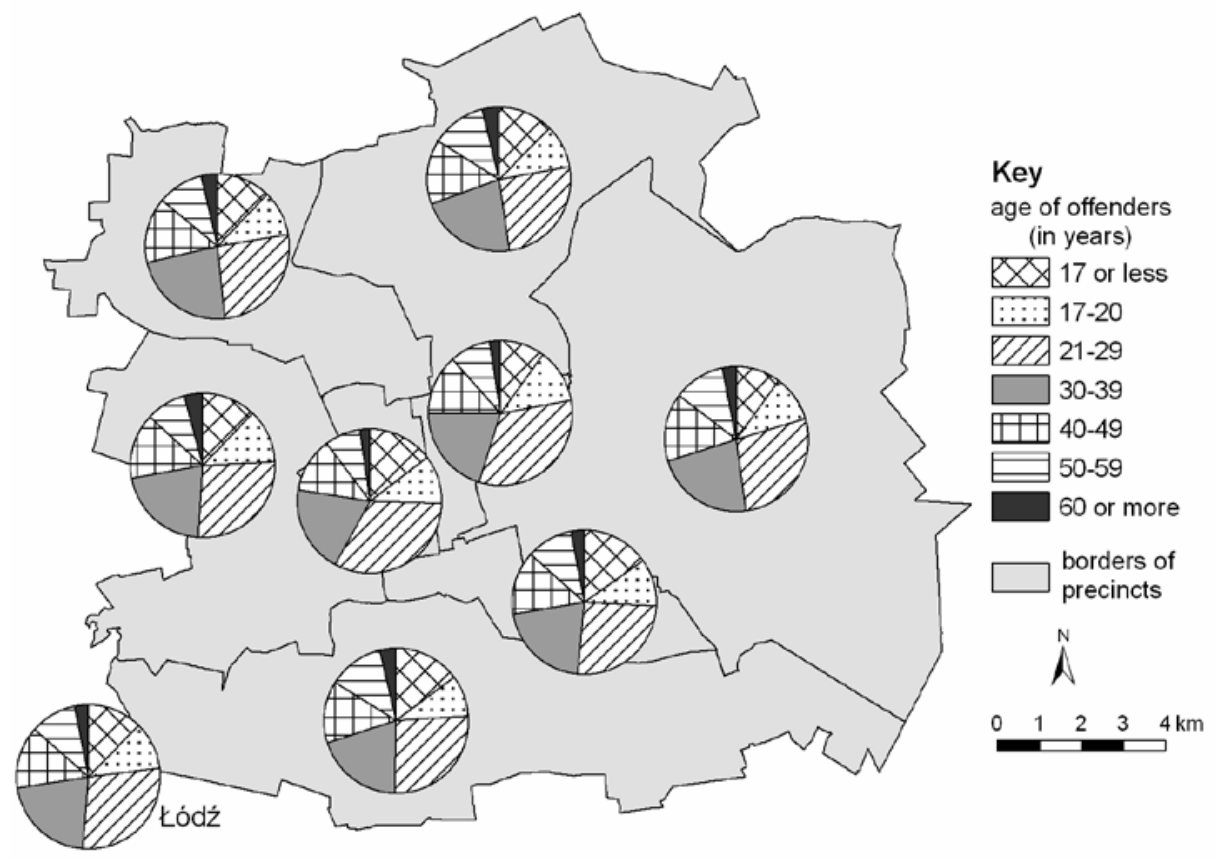

Fig. 4. Age patterns of people suspected of committing offences per precinct in Łódź in 2006-2010 (own work)

Based on available police data regarding Łódź, one can confirm general regularities regarding the age of suspects in different categories of offences (Fig. 5). On average, the youngest are suspected of committing criminal offences - median of the their age was 26.3 (in the case of people suspected of criminal offences against property, the median was 26.1, whereas in the case of offences against life or health - only 21). Older people are suspected of committing traffic and other offences (median - 33.7), while the oldest people are suspects in commercial cases (median - 40). In the case of criminal offences, the largest percentage of offences was recorded for the 17-20 age group - there were 272 suspects per every 10,000 inhabitants at that age (this group consisted of 169 suspects of committing criminal offences against property and 36 suspects of committing criminal offences against life or health - for both groups, the values for this age group were the highest). The highest intensity of commercial offences exists among people in their forties (33) while traffic and other offences are mostly committed by people in their twenties (79). 


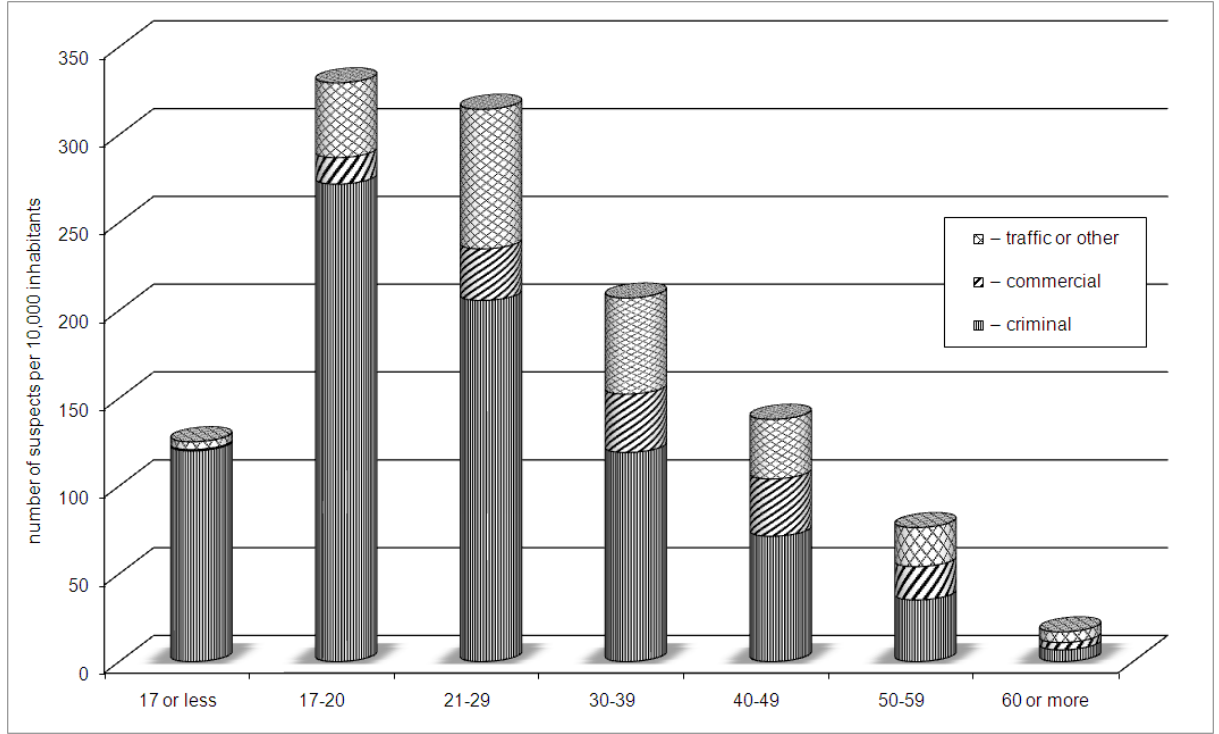

Fig. 5. Intensity index of the number of suspects per age group in Łódź in 2006-2010 (own work)

I decided to conduct the analysis of suspects of criminal offences separately for two main groups of offences: acts against life or health (Fig. 6) and acts against property (Fig. 7). There are not that many criminal offences against life or health in Łódź (591 suspects annually), yet this a group of the most severe, serious acts which arouse most anxiety related to the lack of security among the inhabitants - as potential victims. The existence of suspects of committing such acts in Łódź entails the following facts (Fig. 6):

- the most common offences in this group were robberies or extortions, brawling or battery and health impairment;

- juveniles (31\%), people in their twenties (24\%) and young offenders (19\%) constituted the largest age group of suspects - in general, people under 20 are suspected of committing half of all the offences against life or health;

- the highest share of juveniles and young offenders among all suspects within the analysed group of torts was recorded in eastern Bałuty (up to 67\%), eastern Polesie (58\%) and southern Górna (51\%);

- the Śródmieście precinct recorded a high share of people in their twenties among all suspects;

- the intensity index of the number of suspects for the entire population of detected suspects was 8 people per 10,000 inhabitants. However, it is much higher among young offenders, juveniles and people in their twenties reaching 36, 20 and 16 people respectively per 10,000 inhabitants. 
- within the city, the value of the intensity index of the number of suspects varies: the highest values are specific for precinct I - in Śródmieście (19 people per 10,000 inhabitants) and IV - in eastern Polesie (14);

- precinct I recorded exceptionally high intensity of offences against life or health among people aged 17-20 (81 suspects per 10,000 inhabitants) and among people in their twenties (51), whereas eastern Polesie recorded the highest intensity of criminal activity among juveniles (40). Low numbers of suspects of committing the above-mentioned offences were recorded in precincts III, VI and VII (around 5 suspects in each per 10,000 inhabitants). Therefore, high numbers of suspects apply to precincts where a considerable portion of the area is occupied by city-centre developments whereas in precincts without such developments, the numbers of suspects of the most severe criminal offences is low.

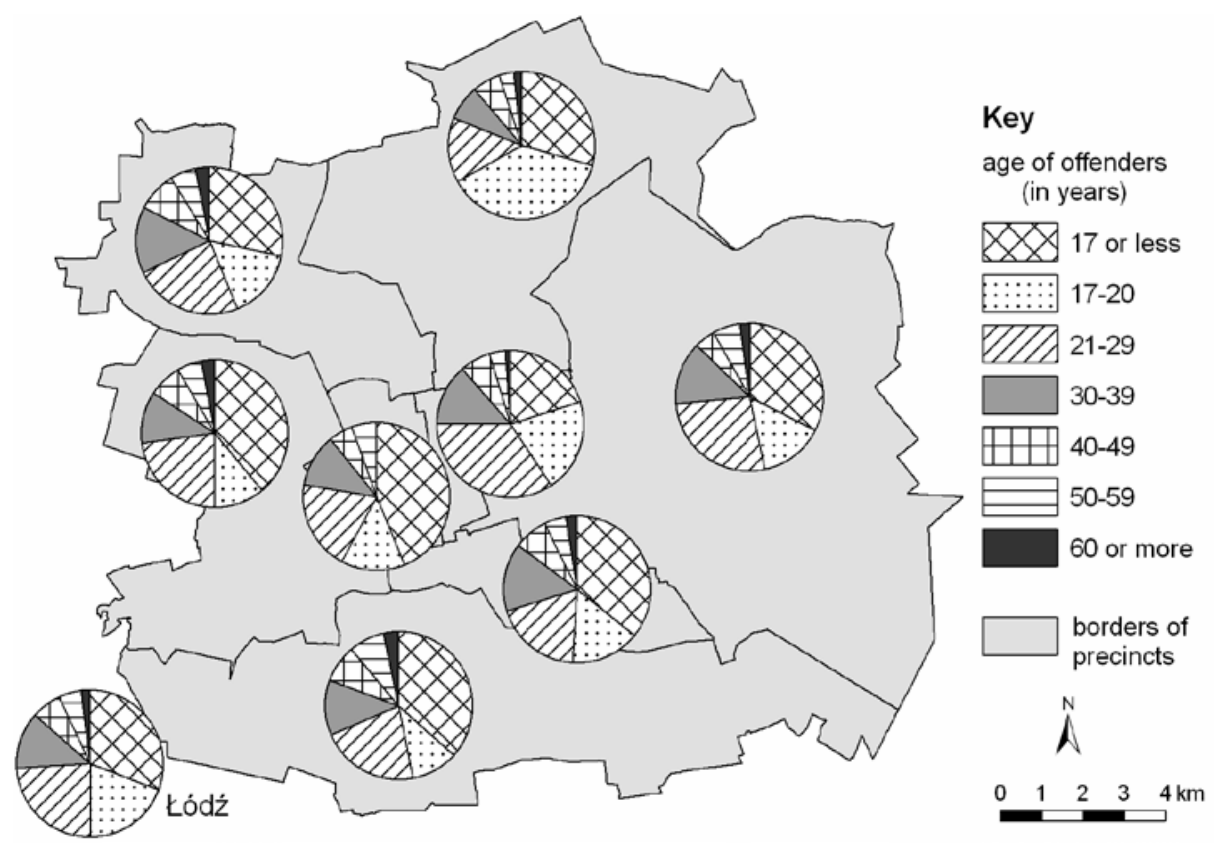

Fig. 6. Age patterns of people suspected of committing criminal offences against life or health in Łódź in 2006-2010 (own work)

The most common acts committed in Łódź are offences against property. Also suspects of such offences constitute 38\% of the total number of detected perpetrators (which amounts to $58 \%$ of the total group of suspects of criminal offences). The highest share in offences against property is maintained among people in their twenties (29\%) and in their thirties (18\%), juveniles (17\%) and young offenders (15\%). Together, they are the suspects in $79 \%$ of all cases. In the case of the discussed group of offences, the majority of juvenile suspects 
were detected in both precincts in Górna (both up to 25\%) and in eastern Polesie (22\%). In the remaining precincts, the largest suspect groups include people aged 21-29 (Fig. 7). The highest number of suspects of offences against property were recorded in precincts I and IV (103 and 94 suspects per 10,000 inhabitants were recorded there respectively) where it is nearly twice as high as the average value for Łódź. On the other hand, when analysing age patterns, generally the highest number of suspects in the discussed group of acts was recorded among young offenders (169 per 10,000 inhabitants), followed people in their twenties (121) and juveniles (67). The spatial patterns of the age of suspects illustrated by Fig. 7 is clearly diverse.

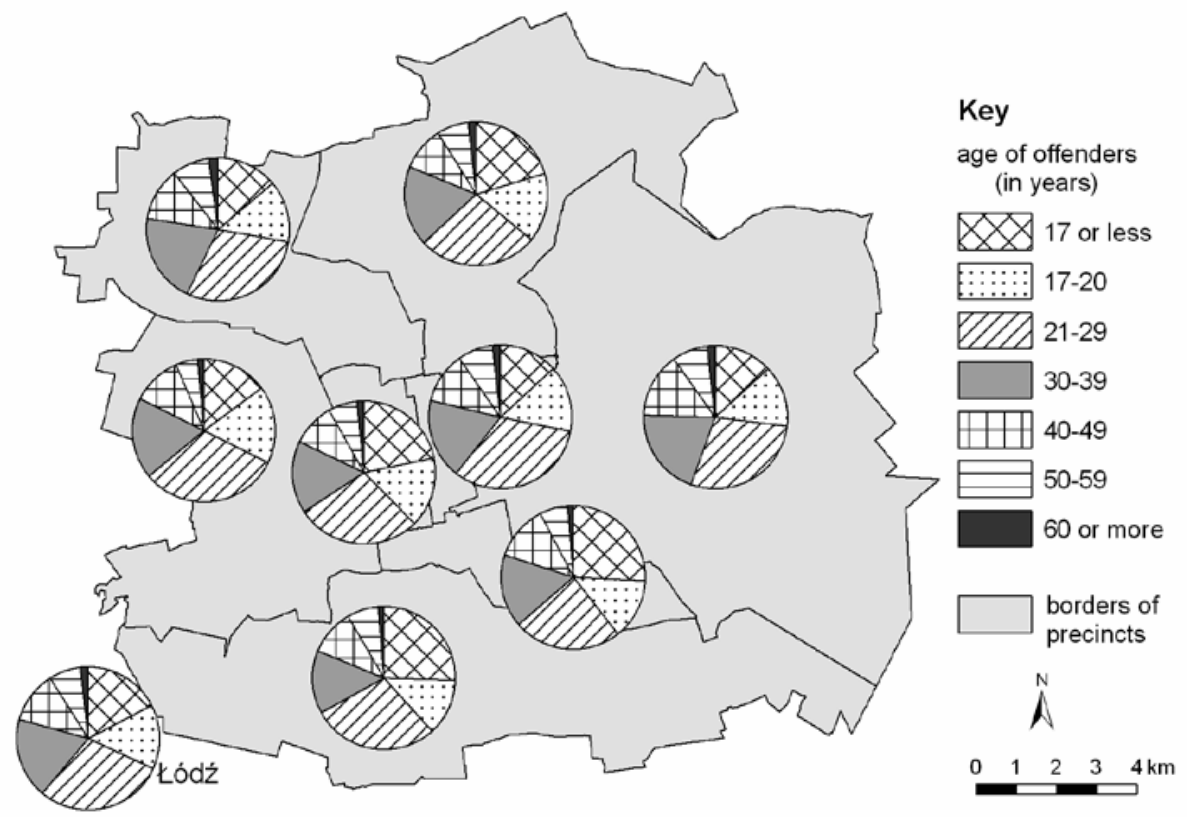

Fig. 7. Age patterns of people suspected of committing criminal offences against property per precinct in Łódź in 2006-2010 (own work)

In the case of the largest (and the most dangerous) group of offences criminal offences - a high share and tendency towards crime occurs among juveniles. They are most often detected in precincts I and IV which, as it seems, include the largest numbers of the so-called enclaves of poverty. Łódź sociologists have found that the quality of life in childhood and impoverished neighbourhood constitute significant factors in the process of "inheriting" poverty between generations and of exclusion. People raised by such an enclave may be inflicted with decreased aspirations for professional or material success while negative role models may inspire children and the youth to enter the path of illegal acts. As a result children and the youth who are brought in the enclaves 
of Łódź poverty adopt the style of life present there as normal and obvious (Petelewicz, Warzywoda-Kruszyńska 2010).

As indicated in the map, the age patterns of suspects in commercial offences is largely similar throughout the precincts (Fig. 8). Significant differences may be found in the case of the share of suspects in their twenties and those in their fifties, yet those differences do not form any significant spatial regularities. Such regularities may be found, however, in the case of diversification of the values of intensity index of the number of suspects. While the general value of the index for Łódź is 18 suspects, in Śródmieście it reaches up to 40 suspects per 10,000 inhabitants. Similarly high values were recorded in eastern Polesie and in western Bałuty (31 and 25 suspects per 10,000 inhabitants respectively). In the remaining areas, the values are lower than for Łódź in general with the lowest share of suspects being recorded in western Polesie, eastern Bałuty and southern Górna. This spatial patterns is virtually duplicated by the intensity of the discussed index of suspects calculated for specific age groups. Low and high values for specific age groups apply to the same areas. The largest disproportions were recorded between Śródmieście and western Polesie, where in precinct I the indexes are nearly four times higher for three age groups between 21-49 years of age.

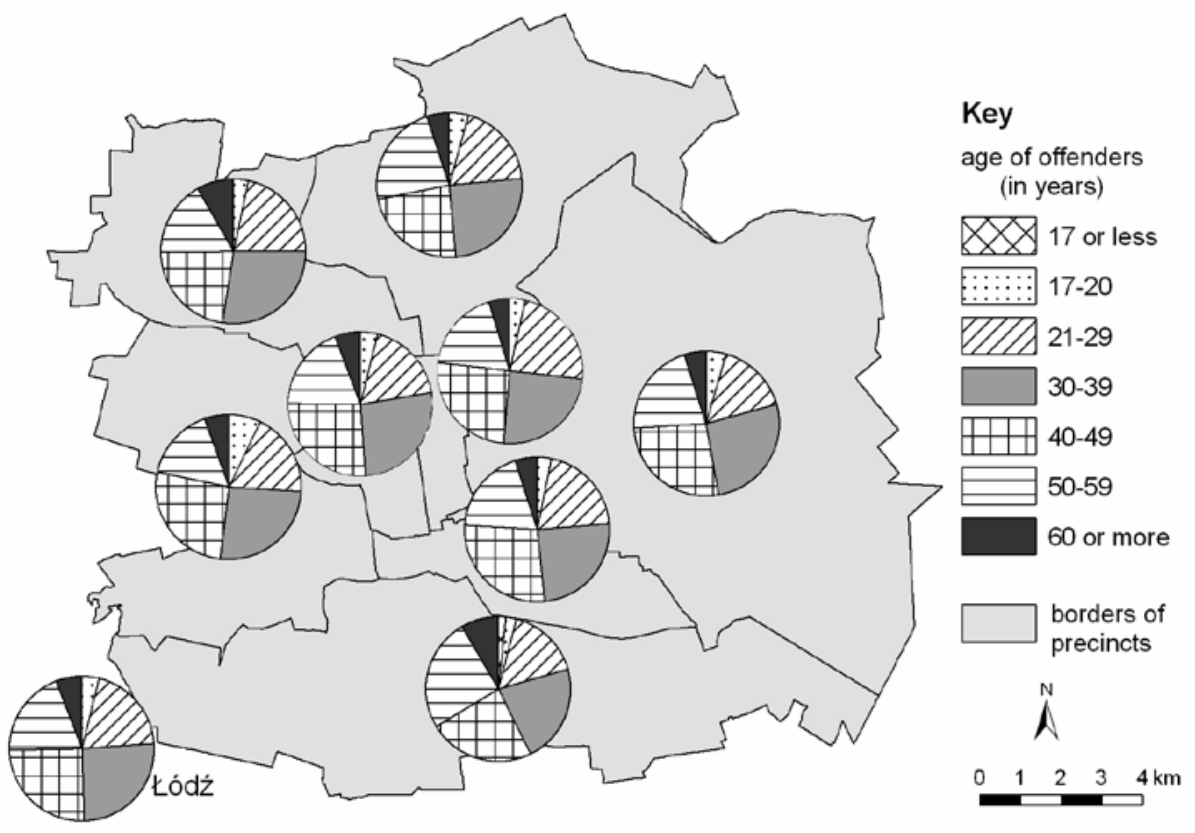

Fig. 8. Age patterns of people suspected of committing commercial offences per precinct in Łódź in 2006-2010 (own work) 
In the case of traffic and other offences, age patterns are different, additionally indicating spatial differences (road offences are dominant in this group of acts in Łódź - 58\%). The largest number of suspects of such offences were observed in precincts IV and I where the value of the intensity index reached 72 and 50 suspects per 10,000 people respectively. Such high values are mainly a result of the index for people in the 21-29 age group. In precinct VI, this value reached 265 suspects per 10,000 people. Particularly in the case of traffic offences, there is a visible rapid steady decrease of the tendency to commit such offences with age.

\subsection{CONCLUSIONS}

Upon discussing the spatial diversification of sex and age patterns of people suspected of committing offences in Łódź in 2006-2010, I decided to compare those patterns in order to verify the thesis regarding the existence of problem areas within the city which would display considerable shares of women and young offenders among the people potentially infringing the rule of law. I compared these figures with general crime rates within specific precincts. Fig. 9 shows that individual phenomena entail different values for specific areas. There are no tendencies according to which one phenomenon would condition another. It rather seems that the area of each precinct possesses a specific structure for the analysed phenomena. Neither sex nor age or crime rate condition the variability of the remaining phenomena.

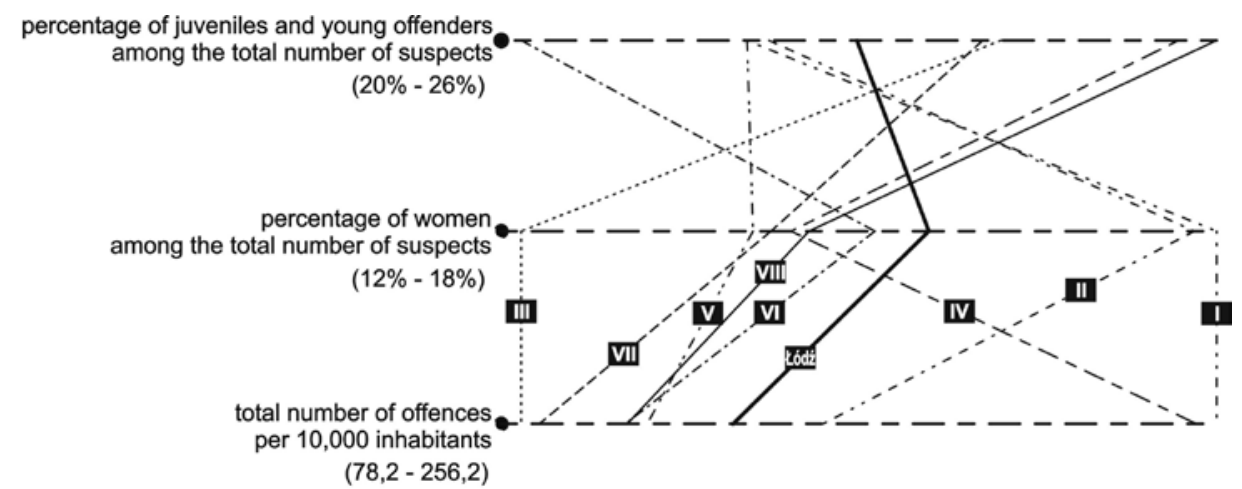

Fig. 9. Age, sex and crime rate per precinct in Łódź in 2006-2010

(own work using the OpenGeoDa 1.0.1 software; $\mathbf{m}$ - police precincts numbers)

On the basis of the analyses of selected demographic features of people suspected of committing offences in Łódź, one can confirm the general principles of criminology regarding the influence of sex and age on the tendency 
towards committing illegal acts. However, the results of the study indicate that the significance of the influence of the studied features of the suspects is not clear. Even within a single city, I observed that the number of suspects in specific city population groups is not constant. Even though general rules regarding crime as a phenomenon committed by men and young people anywhere in Łódź are obvious, the intensity index for those groups of population indicate significant spatial variability. Thus, one could argue that the residential environment - while retaining the general regularities regarding its demographic specificity - constitutes a significant element modifying people's tendency towards committing torts.

\section{BIBLIOGRAPHY}

Agnew R., 2003, An integrated theory of the adolescent peak in offending, „Youth and Society”, 34, pp. 263-302.

Błachut J., Gaberle A., Krajewski K., 2007, Kryminologia, Arche, Gdańsk.

Brown S.E., Esbensen F.-A., Geis G., 2010, Criminology: explaining crime and its context, LexisNexis, New Providence.

Cohen L.E., Land K.C., 1987, Age structure and crime: symmetry versus asymmetry and the projection of crime rates through the 1990s, „American Sociological Review”, vol. 52, pp. 170-183.

Hołyst B., 2009, Kryminologia, LexisNexis, Warsaw.

Laskowski A., Rejzner A., Tokarczyk E., 1996, Demoralizacja i przestępczość dzieci i młodzieży. Atlas, Centrum Metodyczne Pomocy Psychologiczno-Pedagogicznej MEN, Warsaw.

Leśniak M., 1998, Kobieta i przestępstwo [in:] Urban B. (ed.), Problemy współczesnej patologii społecznej, Wydawnictwo UJ, Cracow, pp. 165-175.

Mordwa S., 2013, Przestępczość i poczucie bezpieczeństwa w przestrzeni miasta. Przykład Łodzi, Wydawnictwo UŁ, Łódź.

Morgan L.A., Kunkel S.R., 2007, Aging, society and the life course, Springer, New York.

Petelewicz M., Warzywoda-Kruszyńska W., 2010, Bieda $w$ dzieciństwie jako zagrożenie utrwaleniem biedy $i$ wykluczenia społecznego w przyszłości, Wydawnictwo Biblioteka, Łódź.

Reid S.T., 2000, Crime and criminology, McGraw-Hill, Boston.

Rotolo T., Tittle C.R., 2006, Population size, change, and crime in U.S. cities, „Journal of Quantitative Criminology”, vol. 22 (4), pp. 341-367.

Siegel L.J., 2012, Criminology, Wadsworth, Belmont.

South S.J., Messner S.F., 2000, Crime and demography: multiple linkages, reciprocal relations, „Annual Review of Sociology”, vol. 26, pp. 83-106.

Steffensmeier D, Allan E.A., 1996, Gender and crime: toward a gendered theory of female offending, „Annual Review of Sociology”, vol. 22, pp. 45-87. 
Szczepański J., 1972, Elementarne pojęcia socjologii, PWN, Warsaw.

Treadwell J., 2006, Criminology, SAGE, London.

\section{STRESZCZENIE}

\section{STRUKTURA WIEKU I PLCI OSÓB PODEJRZANYCH O POPELNIENIE PRZESTĘPSTW W LODZI}

Badanie struktur demograficznych osób popełniających przestępstwa ma długotrwałą tradycję $\mathrm{w}$ dorobku różnych dyscyplin naukowych zajmujących się analizą różnych kwestii związanych z przestępczością. Interesujące jest bowiem dociekanie odpowiedzi na pytanie dlaczego w populacjach o określonej strukturze niektóre jednostki popełniają przestępstwa, podczas gdy inne zdecydowanie powstrzymują się od takich działań. Spośród cech demograficznych wpływ na występowanie zachowań przestępczych i dewiacyjnych mają: wiek, płeć (biologiczna i społeczna), rasa, małżeńskość, rozrodczość, migracje, redystrybucja przestrzenna ludności. Twierdzenie, że istnieje związek między płcią i wiekiem a natężeniem przestępczości jest jednym z najstarszych i powszechnie akceptowanych we współczesnej kryminologii. $\mathrm{Na}$ całym świecie uzasadnione jest wskazywanie na mężczyzn jako głównych sprawców przestępstw, także w przypadku struktury wieku przestępców znana jest prawidłowość o spadku skłonności do dokonywania czynów przestępczych wraz $\mathrm{z}$ wiekiem potencjalnego sprawcy. W wielu teoriach dowodzi się, że najwyższe natężenie przestępczości jest wśród osób będących w okresie dojrzewania i maleje wśród coraz starszych roczników. Okazuje się jednak, że mimo ewidentnego spadku skłonności do popełniania przestępstw w coraz starszych grupach wiekowych, zauważalne są istotne różnice między udziałami poszczególnych grup wiekowych dokonujących deliktów, które porównywane są dla różnych obszarów bądź lokalizacji. Odnośnie wieku sprawców przestępstw podstawowa jest prawidłowość: zależność między skłonnością do popełniania przestępstw a wiekiem jest odwrotna, co oznacza spadek tej skłonności u osób coraz to starszych. Także w tym przypadku fenomen ten ma swój wymiar społeczny - ale także przestrzenny. Celem tego opracowania jest udowodnienie, że w przypadku struktury płci i wieku nawet w przestrzeni tego samego miasta zmienne są proporcje między różnymi grupami osób podejrzanych o popełnienie przestępstw.

W wyniku analiz dotyczących wybranych cech demograficznych osób podejrzanych o popełnienie przestępstw w Łodzi potwierdzono ogólne prawa kryminologiczne dotyczące znaczenia wpływu płci i wieku na skłonność ludzi do popełniania deliktów. Jednak w przypadku przedstawionych wyników badań okazało się, że znaczenie wpływu badanych cech podejrzanych nie jest jednoznaczne. Nawet w przypadku przestrzeni jednego miasta zauważono bowiem, że natężenie występowania podejrzanych w różnych grupach populacji mieszkańców nie jest stałe. Mimo, że ogólne prawidłowości dotyczące przestępczości jako zjawiska popełnianego głównie przez mężczyzn i ludzi młodych wszędzie w przestrzeni Łodzi są oczywiste, to już wskaźniki natężenia przestępstw dla tych grup populacji wykazują istotną zmienność przestrzenną. Można 
zatem wnioskować, że środowisko mieszkaniowe - przy zachowaniu ogólnych prawidłowości o charakterze demograficznym - stanowi znaczący element modyfikujący skłonność osób do popełniania deliktów.

Dr Stanisław Mordwa

Katedra Gospodarki Przestrzennej i Planowania Przestrzennego

Wydział Nauk Geograficznych, Uniwersytet Łódzki 